\title{
PERBEDAAN PENGARUH ANTARA METODE LATIHAN SECARA TERUS MENERUS DAN DISELINGI ISTIRAHAT TERHADAP HASIL FREE THROW BOLA BASKET PADA MAHASISWA PUTRA PKO FKIP UTP SURAKARTA
}

\author{
Oleh: Wisnu Mahardika $1^{\text {st }}$, Agus Supriyoko $2^{\text {nd }}$ \\ Wisnu.mahardika@gmail.com \\ ABSTRAK
}

Universitas Tunas Pembangunan Surakarta, mempunyai program pendidikan kepelatihan olahraga dengan berbagai kelebihan dan kekurangan dalam setiap cabang olahraganya. Salah satu cabang yang sangat di gemari oleh masyarakat adalah permainan bola basket. Dengan mengedepankan kualitas teknik dan kondisi fisik dalam setiap program latihannya, permainan bola basket menjadi permainan yang menarik dan berkualitas. Terkhusus dalam melakukan free throw dalam permainan bola basket dipenelitian ini diberikan metode latihan secara terus menerus dan diselingi istirahat.

Mahasiswa semester V Prodi Pendidikan Kepelatihan Olahraga FKIP UTP Surakarta pada umumnya yang belum menguasai teknik free throw dalam bola basket, merasa belum siap bahkan belum memiliki kekuatan yang memadai, sehingga mengalami kesulitan untuk melakukan kemampuan free throw dalam bola basket. Kurangnya sarana yang kurang efektif merupakan faktor yang dapat mempengaruhi rendahnya peningkatan kemampuan free throw dalam bola basket. Selain itu, jarang sekali seorang dosen maupun pelatih menciptakan variasi-variasi pembelajaran yang disesuaikan dengan kondisi dan kemampuan mahasiswanya. Kondisi yang tidak memungkinkan untuk membelajarkan mahasiswa dengan sarana yang ada, menuntut dosen maupun pelatih berkreativitas agar tujuan pembelajaran dapat tercapai dengan baik.

Fokus penelitian adalah metode latihan secara terus menerus dan diselingi istirahat dengan fokus utama pada penerapan intensitas latihan untuk meningkatkan teknik dasar shooting terutama free throw dalam permainan bola basket. Kesimpulannya adalah Metode latihan diselingi istirahat lebih baik pengaruhnya dari pada metode latihan terus menerusterhadap hasilfree throw, kelompok 1 (metode terus menerus) adalah 18.863\% < kelompok 2 (metode diselingi istirahat) adalah $19.226 \%$.

Keywords : Permainan Bola basket, metode latihan, permainan Bola Basket. 
Perbedaan pengaruh Antara Metode Latihan Secara Terus Menerus Dan Diselingi Istirahat Terhadap Hasil Free Throw Bola Basket Pada Mahasiswa Putra PKO FKIP UTP Surakarta Oleh: Wisnu Mahardika $1^{\text {st }}$, Agus Supriyoko $2^{\text {nd }}$

\section{A. PENDAHULUAN}

Menurut daftar perkembangan permainan bola basket di seluruh dunia tidak dipungkiri perkembangannya sangat luar biasa pesatnya. Permainan ini merupakan olahraga yang dimainkan oleh lima orang dalam tiap regu, dimana dalam permainan bolabasket terdapat dua tim yang bertanding dengan tujuan utamanya adalah untuk memasukan bola ke dalam keranjang lawan. Olahraga bola basket mulai dimainkan di sekolah-sekolah, barak militer dan juga di persatuan gereja. Bola basketpun terus berkembang dan mendapat respon yang baik dari berbagai lapisan masyarakat, baik kaum remaja maupun orang dewasa. Sehingga bermunculan kompetisi olahraga bola basket, baik kompetisi profesional maupun kompetisi amatir. Tidak hanya dikompetisi lokal tetapi juga kompetisi profesional NBA merupakan kompetisi bola basket yang profesional yang terbaik dan menjadi kiblat kompetisi bola basket di seluruh dunia.

Perkembangan bola basket di Indonesia dibawa oleh perantau China. Bola basket berkembang pesat di kota-kota besar, seperti Semarang, Jakarta, Bandung, Yogyakarta dan Medan. Pada awal masuk ke Indonesia permainan bola basket hanya dimainkan di sekolahsekolah China, hingga akhirnya pada tahun 1948 bola basket dimainkan di PON I di kota Solo. Sejak saat itu olahraga bola basket selalu dipertandingkan di ajang PON I. Semakin lama olahraga bola basketpun semakin diminati oleh kalangan msyarakat dari berbagai golongan, khususnya di daerah perkotaan.Dengan semakin populernya olahraga bola basket, maka banyak diadakan turnamen profesional yang memperebutkan trofi dan juga hadiah.Hal ini menjadikan banyak kaum muda yang berlatih bola basket, agar dapat bermain bola basket dengan baik dan menjadi pemain profesional. Turnamen yang menjadi wadah olahraga bola basket professional di Indonesia adalah IBL yang melahirkan pemain-pemain hebat dimana sebagian dari para pemain menjadi tulang punggung tim nasional bola basket Indonesia.

Selain turnamen yang bertaraf nasional, olahraga bola basket juga di pertandingkan dikalangan amatir dan juga kalangan pelajar.Pertandingan bola basket juga sering diadakan pada kelompok umur yang bertujuan untuk mencari bakat pemain bola basket yang mempunyai kualitas yang baik. Hal tersebut menjadikan klub-klub basket di Indonesia mengadakan pembinaan pada usia muda.

Dalam suatu latihan seorang pelatih dapat menentukan metode latihan yang digunakan untuk meningkatkan keterampilan tertentu. Metode latihan secara terus menerus adalah 
Perbedaan pengaruh Antara Metode Latihan Secara Terus Menerus Dan Diselingi Istirahat Terhadap Hasil Free Throw Bola Basket Pada Mahasiswa Putra PKO FKIP UTP Surakarta Oleh: Wisnu Mahardika $1^{\text {st }}$, Agus Supriyoko $2^{\text {nd }}$

metode latihan yang berfokus pada latihan intensitas itu sendiri secara terus menerus. Sedangkan metode latihan diselingi istirahat merupakan metode latihan dengan fokus pada teknik gerakan dengan istirahat.

Berdasarkan pemaparan diatas maka penulis memilih judul penelitian sebagai berikut," PerbedaanPengaruh Antara Metode Latihan Secara Terus Menerus Dan Diselingi Istirahat Terhadap Hasil Free Throw Bola basket Pada Mahasiswa Putra PKO FKIP UTP Surakarta".

\section{B. METODE PENELITIAN}

Metode penelitian yang digunakan adalah metode deskriptif studi korelasional. Dalam hal ini Sugiyanto berpendapat bahwa melalui studi korelasional untuk mengukur variable yang diminati. Hubungan antara variabel ditentukan dengan menggunakan koefisien yang dihitung dengan teknik analisis statistik". Besar sampel yang digunakan dalam penelitian ini adalah 30 siswa, yang diperoleh dengan teknik purposive sampling.

Permainan yang dilakukan dua tim dengan setiap tim 5 pemain dalam setiap timnya, tujuan permainan bola basket adalah untuk memasukkan bola ke dalam keranjang lawan sebanyak mungkin. Hal ini sesuai dengan pengertian bola basket menurut Sucipto, Dian Budiana, Lukmanul Hakim Lubay dan Jajat Darajat (2010:23) "bola basket adalah olahraga beregu yang dimainkan dengan cara memantulkan bola, serta menembak bola kedalam keranjang lawan. Setiap regu terdiri dari lima orang dan berusaha memasukkan bola ke dalam keranjang lawannya dan mencegah regu lawan memasukkan bola kedalam keranjang kita". Sedangkan menurut Agus Margono (2010:33) menyatakan “ bahwa bola basket dimainkan oleh dua regu yang masing-masing terdiri dari 5 orang pemain. Tiap regu berusaha memasukkan bola ke keranjang lawan dan berusaha mencegah lawan memasukkan bola atau mencetak angka”.

Dalam peraturan permainan bola basket pasal 1 (PERBASI, 1999), dikutip dari buku Sucipto et al (2010:23) Pengertian bola basket yaitu "bola basket dimainkan oleh dua regu yang masing - masing regu terdiri dari 5 orang pemain. Tiap regu berusaha memasukkan bola kekeranjang regu lawan dan mencegah regu lawan memasukkan bola atau membuat angkm a / skor. Bola boleh dioper, dilempar, ditepis, digelindingkan atau dipantulkan/didrible kesegala arah, sesuai peraturan". 
Perbedaan pengaruh Antara Metode Latihan Secara Terus Menerus Dan Diselingi Istirahat Terhadap Hasil Free Throw Bola Basket Pada Mahasiswa Putra PKO FKIP UTP Surakarta Oleh: Wisnu Mahardika $1^{\text {st }}$, Agus Supriyoko $2^{\text {nd }}$

Dari beberapa pengertian diatas dapat disimpulkan bahwa pengertian permainan bola basket adalah permainan yang dilakukan oleh dua tim. Dimana terdapat lima orang pemain tiap timnya. Tujuan permainan bola basket adalah untuk memasukkan bola ke keranjang lawan sebanyak-banyaknya dan berusaha mencegah lawan melakukan upaya serupa.

Olahraga bola basket merupakan olahraga yang kompleks dan melibatkan berbagai unsur kemampuan, seperti koordinasi, ketepatan, kelincahan, daya tahan, kekuatan dan lain sebagainya. Seperti yang dikatakan Iman Sodikun (1991) yang dikutip dari buku Sucipto et al (2010:27) menyatakan "bola basket termasuk jenis permainan yang kompleks gerakannya. Artinya gerakannya terdiri dari gabungan unsur-unsur gerak yang terkoordinasi rapi sehingga pemain pemain dapat bermain dengan baik". Dari pengertian ini maka agar dapat bermain bola basket dengan baik dan benar, maka seorang pemain harus menguasai berbagai kemampuan serta koordinasi yang baik pula.

\section{Latihan Free Throw Dengan Metode Latihan Secara terus menerus}

MenurutSukadiyanto (2010:32) "latihan terus menerus adalah metode yang di dalamnya membutuhkan waktu yang lama dan harus bertahap pengaruh latihan tidak dapat langsung diadaptasi secara mendadak untuk mencapai kemampuan maksimal”

Latihan dengan secara terus menerus dapat pula diterapkan dalam latihan free throw. Latihan yang diterapkan dalam penelitian ini yaitu latihan free throw bola basket dengan sejumlah bola yang disediakan. Dalam latihan ini pemain melakukan gerakan free throw secara kontinyu sebanyak 10 kali free throw dan latihan yang secara terus menerus ini memakan waktu kurang lebih di bawah tiga menit dalam satu setnya. Dikarenakan dalam latihan waktunya kurang dari 3 menit, maka sistem energi yang digunakan adalah sistem anaerobik. Dengan melakukan gerakan free throw secara berulang-ulang maka akan terjadi perbaikan koordinasi sistem syaraf, yang mengarah pada perbaikan pola gerak free throw. Sehingga dengan latihan diharapkan dapat meningkatkan keterampilan free throw. 
Perbedaan pengaruh Antara Metode Latihan Secara Terus Menerus Dan Diselingi Istirahat Terhadap Hasil Free Throw Bola Basket Pada Mahasiswa Putra PKO FKIP UTP Surakarta Oleh: Wisnu Mahardika $1^{\text {st }}$, Agus Supriyoko $2^{\text {nd }}$

\begin{tabular}{|c|c|}
\hline \begin{tabular}{lll}
\multicolumn{1}{c}{ Kelebihan } & Latihan & Terus \\
Menerus & &
\end{tabular} & $\begin{array}{l}\text { Kelemahan } \\
\text { Menerus }\end{array}$ \\
\hline $\begin{array}{l}\text { 1. Penguasaan terhadap pola gerakan } \\
\text { teknik free throw bola basket akan } \\
\text { lebih cepat tercapai. Karena dalam } \\
\text { latihan ini secara terus menerus dan } \\
\text { berkelanjutan ini akan } \\
\text { memungkinkan terhadap } \\
\text { pembentukan pola gerakan yang } \\
\text { cepat. }\end{array}$ & $\begin{array}{l}\text { 1.Penguasaan teknik gerakan yang } \\
\text { sempuma akan sulit tercapai, sebab } \\
\text { dengan latihan secara terus menerus } \\
\text { akan menyebabkan kelelahan dan ini } \\
\text { akan berpengaruh terhadap } \\
\text { kesempurnaan gerakan yang } \\
\text { dilakukan }\end{array}$ \\
\hline $\begin{array}{l}\text { 2. Dengan latihan yang terus } \\
\text { menerus, maka dapat } \\
\text { meningkatkan keterampilan } \\
\text { sekaligus meningkatkan kondisi } \\
\text { fisik khususnya daya tahan. }\end{array}$ & $\begin{array}{l}\text { 2. Pengontrolan dan perbaikan terhadap } \\
\text { teknik gerakan sulit dilakukan, sebab } \\
\text { tidak ada waktu istirahat }\end{array}$ \\
\hline
\end{tabular}

\section{Latihan Free Throw Dengan Metode Latihan Diselingi istirahat}

Metode latihan diselingi istirahat ini dapat pula diterapkan dalam permainan bolabasket khususnya dalam latihan untuk meningkatkan keterampilan free throw bola basket. Menurut Sukadiyanto(2010:41) "Latihan diselingi istirahat, yaitu pemberian waktu istirahat yang diberikan pada saat antar set atau antar repetisi(ulangan)"

Latihan free throw bola basket diselingi istirahat yang diterapkan dalam penelitian ini adalah latihan free throw bola basket sebanyak 10 kali free throw bola basket dengan setiap 1 kali free throw bola basket diselingi istirahat selama 30 detik atau bergiliran dengan teman. Dengan adanya selingan istirahat dalam satu set, sistem energi yang digunakan adalah sistem aerobik. Karena sistem aerobik sangat efisien dan tidak menimbulkan kelelahan, sistem ini merupakan sumber energi otot yang lebih disukai.Selama latihan dengan intensitas sedang dan rendah, metabolisme aerobik benar-benar menyediakan seluruh ATP yang dibutuhkan oleh otot ini, sistem pernafasan jantung dapat menggerakkan oksigen ke otot secara teratur. Maka kegiatan olahraga yang memerlukan penggunaan oksigen dengan intensitas sedang sangat tergantung pada sistem metabolisme aerobik. 
Perbedaan pengaruh Antara Metode Latihan Secara Terus Menerus Dan Diselingi Istirahat Terhadap Hasil Free Throw Bola Basket Pada Mahasiswa Putra PKO FKIP UTP Surakarta Oleh: Wisnu Mahardika $1^{\text {st }}$, Agus Supriyoko $2^{\text {nd }}$

\begin{tabular}{|c|c|}
\hline $\begin{array}{l}\text { Kelebihan Latihan Terus } \\
\text { Menerus }\end{array}$ & $\begin{array}{l}\text { Kelemahan Latihan Terus } \\
\text { Menerus }\end{array}$ \\
\hline $\begin{array}{l}\text { 1. Penguasaan terhadap pola gerakan } \\
\text { teknik free throw bolabasket akan } \\
\text { lebih sempurna. Karena dalam } \\
\text { latihan ini pemain selalu mendapat } \\
\text { waktu istirahat yang cukup sehingga } \\
\text { pemain tersebut akan dapat } \\
\text { melakukan teknik gerakan free } \\
\text { throw bolabasket secara sempuma. }\end{array}$ & $\begin{array}{l}\text { 1. Penguasaan teknik gerakan agak } \\
\text { lambat karena sering diselingi } \\
\text { istirahat. Hal ini disebabkan pola } \\
\text { gerakan yang sudah terbentuk } \\
\text { berkurang selama istirahat. }\end{array}$ \\
\hline $\begin{array}{l}\text { 2. Perbaikan terhadap pola gerakan } \\
\text { yang dilakukan akan mudah } \\
\text { dilakukan, yaitu pada waktu } \\
\text { istirahat. Dengan adanya perbaikan- } \\
\text { perbaikan terhadap gerakan yang } \\
\text { dilakukan, maka penguasaan } \\
\text { terhadap teknik free throw } \\
\text { bolabasket akan lebih baik. }\end{array}$ & $\begin{array}{l}\text { 2. Prioritas dalam latihan mi hanya } \\
\text { terbatas pada teknik gerakan, tanpa } \\
\text { menghiraukan kondisi fisik. }\end{array}$ \\
\hline $\begin{array}{l}\text { 3. Kondisi fisik pemain akan terhindar } \\
\text { dan kelelahan yang berlebihan, } \\
\text { sehingga terhindar } \\
\text { kemungkinan }\end{array}$ & \\
\hline
\end{tabular}

\section{HASIL PENELITIAN}

Perbedaan Pengaruh Latihan Secara Terus Menerus dan Diselingi Istirahat Terhadap Hasil Free Throw bola basket.

Nilai $\mathrm{t}$ antara tes awal dan tes akhir pada kelompok $1=3.4681$, sedangkan $\mathrm{t}_{\text {tabel }}=2,145$. Ternyata t yang diperoleh > dalam tabel, yang berarti hipotesis nol ditolak. Dengan demikian dapat disimpulkan bahwa terdapat perbedaan yang signifikan antara hasil tes awal dan tes akhir pada kelompok 1. Berarti kelompok 1 memiliki peningkatan free throw bolabasket yang disebabkan oleh metode yang diberikan, yaitu dengan metode latihan secara terus menerus. Dalam metode ini pemain mempelajari sesuatu permainan sampai dikuasai dan kemudian mengkombinasikan dengan bagian yang lain, baru dengan dipelajari atau dipraktikkan secara bersama sampai benar-benar dikuasai, sehingga menyebabkan peningkatan free throw bolabasket menjadi lebih baik. 
Perbedaan pengaruh Antara Metode Latihan Secara Terus Menerus Dan Diselingi Istirahat Terhadap Hasil Free Throw Bola Basket Pada Mahasiswa Putra PKO FKIP UTP Surakarta Oleh: Wisnu Mahardika $1^{\text {st }}$, Agus Supriyoko $2^{\text {nd }}$

Nilai $\mathrm{t}$ antara tes awal dan tes akhir pada kelompok $2=3.6754$, sedangkan $\mathrm{t}_{\text {tabel }}=$ 2,145 . Ternyata $t$ yang diperoleh $>\mathrm{t}$ dalam tabel, yang berarti hipotesis nol ditolak. Dengan demikian dapat disimpulkan bahwa terdapat perbedaan yang signifikan antara hasil tes awal dan tes akhir pada kelompok 2. Berarti kelompok 2 memiliki peningkatan free throw bola basket perbedaan yang disebabkan metode yang diberikan, metode latihan diselini istirahat. Dalam metode ini pemain mempelajari elemen gerak secara berkelanjutan, sehingga dapat menyebabkan hasil peningkatan free throw bolabasket menjadi baik.

Dari hasil uji perbedaan yang dilakukan terhadap tes akhir pada kelompok 1 dan 2, diperoleh nilai $\mathrm{t}$ sebesar 3.2208. Sedangkan $\mathrm{t}_{\text {tabel }}=2,145$. Ternyata $\mathrm{t}$ yang diperoleh $<\mathrm{t}$ dalam tabel, yang berarti hipotesis nol ditolak. Dengan demikian dapat disimpulkan bahwa setelah diberikan perlakuan selam 6 minggu, terdapat perbedaan yang signifikan antara hasil tes awal dan tes akhir pada kelompok 1 dan kelompok 2. karena sebelum diberikan perlakuan kedua kelompok berangkat dari titik tolak yang sama, maka perbedaan tersebut adalah karena pengaruh dari metode yang diberikan.

Dalam pelaksanaan metode latihan bahwa pengaruh metode yang digunakan adalah bersifat khusus, sehingga perbedaan karakteristik metode dapat menghasilkan pengaruh yang berbeda pula. Oleh karena itu, kelompok yang diberikan perlakuan metode terus menerusdan metode latihan diselingi istirahat, memiliki pengaruh yang berbeda terhadap hasil peningkatan free throw bola basket. Dengan demikian hipotesis yang menyatakan bahwa ada perbedaan pengaruh setelah diberikan perlakuan antara metode latihan terus menerus dan metode latihan diselingi istirahat terhadap peningkatan free throw bola basket pada mahasiswa putra PKO FKIP UTP Surakarta Tahun 2018, dapat diterima kebenarannya.

Metode Latihan Diselingi IstirahatLebih BaikPengaruhnya Terhadap peningkatan free throw bolabasket.

Kelompok 1 memiliki nilai persentase peningkatan free throw bolabasketsebesar $18.863 \%$, sedangkan kelompok 2 memiliki peningkatan free throw bolabasketsebesar 19.226\%. Dengan demikian dapat disimpulkan bahwa kelompok 2 memiliki persentase peningkatan free throw bola basket yang lebih besar dari kelompok 1 . 
Perbedaan pengaruh Antara Metode Latihan Secara Terus Menerus Dan Diselingi Istirahat Terhadap Hasil Free Throw Bola Basket Pada Mahasiswa Putra PKO FKIP UTP Surakarta Oleh: Wisnu Mahardika $1^{\text {st }}$, Agus Supriyoko $2^{\text {nd }}$

Kelompok 1 (kelompok yang mendapat perlakuan dengan metode latihan terus menerus), ternyata memiliki peningkatan free throw bola basket yang lebih sedikit daripada kelompok 2 (kelompok yang mendapat perlakuan dengan metode latihan diselingi istirahat). Hal ini karena metode latihan diselingi istirahat sangat efektif untuk peningkatan free throw bolabasket. Metode dengan metode latihan diselingi istirahat mempertemukan celah pemisah antara kondisi fisik, kekuatan dan koordinasi yang lebih tepat metodenya. metode ini pemain mempelajari sesuatu bagian sampai dikuasai dan kemudian mengkombinasikan dengan permainan yang lain, baru dengan dipelajari atau dipraktikkan secara bersama sampai benarbenar dikuasai, inilah faktor utama keberhasilan pembelajaran untuk peningkatan free throw bolabasket yang lebih optimal. Sedangkan metode bagian menekankan tiap bagian dikuasai terlebih dahulu dengan baik kemudian baru dilanjutkan penguasaan bagian berikutnya sehingga siswa yang baru belajar akan lebih sempurna dan baik dalam gerakannya sehingga memungkinkan peningkatan free throw bola basket, sedang pengulangan gerakan penggabungan akan diintegrasikan antar bagian sangat kurang, padahal teknik penggabungan antara bermain sangat mempengaruhi hasil yang akan dicapai. Dengan demikian hipotesis yang menyatakan bahwa metode keseluruhan lebih baik pengaruhnya terhadap free throw bola basket pada pemain putra bola basket mahasiswa, dapat diterima kebenarannya.

Berdasarkan hasil pengujian hipotesis dengan uji perbedaan nilai $t$ antara tes awal dan tes akhir pada kelompok 1 (kelompok yang mendapat metode bagian) $=3.4681$, sedangkan $t_{\text {tabel }}=2,145$. Ternyata $t$ yang diperoleh $>t_{\text {tabel }}$, yang berarti hipotesis nol ditolak. Hal ini menunjukkan adanya perbedaan yang signifikan antara hasil tes awal dan tes akhir pada kelompok 1. Kelompok 1memiliki peningkatan free throw bola basket yang disebabkan oleh metode yang diberikan, yaitu metode latihan secara terus menerus.

Pada analisa data yang didapat antara tes awal dan tes akhir pada kelompok 2 (kelompok yang mendapat metode latihan diselingi istirahat $=3.6754$, sedangkan $t_{\text {tabel }}=$ 2,145 . Ternyata $t$ yang diperoleh $>t_{\text {tabel }}$, yang berarti hipotesis nol ditolak. Dengan demikian dapat disimpulkan bahwa terdapat perbedaan yang signifikan antara hasil tes awal dan tes akhir pada kelompok 2. Berarti kelompok 2 memiliki peningkatan free throw bolabasket yang disebabkan oleh metode yang diberikan, yaitu metode latihan diselingi istirahat. Pada analisa data yang lain yaitu pada hasil uji perbedaan yang dilakukan terhadap tes akhir pada 
Perbedaan pengaruh Antara Metode Latihan Secara Terus Menerus Dan Diselingi Istirahat Terhadap Hasil Free Throw Bola Basket Pada Mahasiswa Putra PKO FKIP UTP Surakarta Oleh: Wisnu Mahardika $1^{\text {st }}$, Agus Supriyoko $2^{\text {nd }}$

kelompok 1 dan 2, diperoleh nilai t sebesar 3.2208, sedangkan $t_{\text {tabel }}=2,145$. Ternyata $t$ yang diperoleh $\mathrm{t}<\mathrm{t}_{\text {tabel}}$, yangberarti hipotesis nol ditolak. Hal ini menunjukkan bahwa setelah diberikan perlakuan selama 6 minggu, terdapat perbedaan yang signifikan antara hasil tes awal dan tes akhir pada kelompok 1 dan kelompok 2. Kelompok 1 dan kelompok 2 diberikan perlakuan (treathment) dengan metode yang berbeda.

Perbedaan metode yang diberikan selama proses latihan, akan mendapat respon yang berbeda pula dari subjek, sehingga dapat memberikan pengaruh yang berbeda terhadap pembentukan kemampuan pada subjek penelitian. Oleh karena itu, kelompok yang diberikan perlakuan metode latihan terus menerus dan metode latihan diselingi istirahat memiliki pengaruh yang berbeda terhadap peningkatan free throw bola basket.

Adanya perbedaan yang signifikan antara kelompok 1 dan kelompok 2 maka dilakukan penghitungan nilai perbedaan peningkatan free throw bola basket dalam persen pada kelompok 1 dan kelompok2. Kelompok 1 memiliki nilai persentase free throw bola basket sebesar $18.863 \%$, sedangkan kelompok 2 memiliki nilai persentase peningkatan free throw bola basket sebesar 19.226\%. Hal ini menunjukkan kelompok 2 memiliki peningkatan free throw bola basket yang lebih baik daripada kelompok 1, karena metode keseluruhansangat efektif untuk peningkatan free throw bolabasket. Dalam metode ini pemain mempelajari sesuatu bagian sampai dikuasai dan kemudian mengkombinasikan dengan bagian yang lain, baru dengan dipelajari atau dipraktikkan secara bersama sampai benar-benar dikuasai, sehingga menyebabkan peningkatan free throw bola basket menjadi lebih optimal. Hal inilah yang menjadi faktor utama terbentuknya peningkatan kemampuan free throw bola basket. Dengan peningkatan free throw bola basket yang baik, maka akan mendukung peningkatan free throw bola basket yang lebih optimal. Dari salah satu sisi dalam metode latihan diselingi istirahat pemain mempelajari elemen pergerakan yang lebih banyak dipelajari dan latih dahulu sehingga menjadi tanggapan gerak yang dikuasai, lalu merangkai gerak yang telah dimiliki sebelumnya, dan lebih sudah dalam penggabungan atau koordinasi elemen gerak selanjutnya, sehingga dapat menyebabkan peningkatan free throw bola basket. Namun karena pengulangan gerakan penggabungan akan diintegrasikan antar bagian sangat kurang, padahal teknik penggabungan antar bagian sangat mempengaruhi hasil yang akan 
Perbedaan pengaruh Antara Metode Latihan Secara Terus Menerus Dan Diselingi Istirahat Terhadap Hasil Free Throw Bola Basket Pada Mahasiswa Putra PKO FKIP UTP Surakarta Oleh: Wisnu Mahardika $1^{\text {st }}$, Agus Supriyoko $2^{\text {nd }}$

dicapai, maka dengan menggunakan metode keseluruhan dalam upaya peningkatan free throw bola basket tidak meningkat secara optimal.

\section{SIMPULAN}

Ada perbedaan pengaruh yang signifikan antara metode latihan terus menerus dan diselingi istirahat terhadap hasil free throw bola basket pada mahasiswa putra PKO FKIP UTP Surakarta Tahun 2018. Hal ini dibuktikan dari hasil penghitungan tes akhir masing-masing kelompok yaitu $t_{\text {hitung }}=3.2208$ lebih besar dari pada $t_{\text {tabel }}=2,145$ dengan taraf signifikasi 5\%.Metode latihan diselingi istirahat lebih baik pengaruhnya dari pada metode latihan terus menerus terhadap hasil free throw bola basket pada mahasiswa putra PKO FKIP UTP Surakarta Tahun 2018. Berdasarkan persentase hasil free throw bola basket menunjukkan bahwa kelompok 1 (kelompok yang mendapat perlakuan dengan metode terus menerus) adalah $18.863 \%$ < kelompok 2 (kelompok yang mendapat perlakuan metode diselingi istirahat) adalah $19.226 \%$.

\section{DAFTAR PUSTAKA}

Agus Margono. 2010. Permainan Bola Basket. Surakarta: Universitas Sebelas Maret Press.

Agus Salim. 2007. Buku Pintar Bola Basket. Bandung: Jembar

Akros Abidin. 1999. Buku Penuntun Bola Basket Kembar, Jakarta: PT Raja Grafindo

Andi Suhendro. 1999. Dasar-dasar Kepelatihan. Jakarta: Universitas Terbuka

Apta Mylsidayu \& Febi Kurniawan. 2015. Ilmu Kepelatihan Dasar. Bandung: Alfabeta.

Danny Kosasih, 2008. Fudamental Basket Ball First Step To Win. Semarang: Karangturi Media.

Deborah, A. Wuest \& Charles, A. Bucher. 1995. Foundations of Physical Education and Sport. $12^{\text {th }}$ Edition. St. Louis, Missouri: Mosby-Year Book,Inc.

Gagne, Robert M. 1985. The Condition of Learning. $4^{\text {th }}$ Edition. New York: CBSCollege Publishing. 
Perbedaan pengaruh Antara Metode Latihan Secara Terus Menerus Dan Diselingi Istirahat Terhadap Hasil Free Throw Bola Basket Pada Mahasiswa Putra PKO FKIP UTP Surakarta Oleh: Wisnu Mahardika $1^{\text {st }}$, Agus Supriyoko $2^{\text {nd }}$

Good, Thomas L. \& Brophy, Jere E. 1990. Educational Psychology: A Realistic Approach. $4^{\text {th }}$ Edition. New York: Longman.

Harsono. 2015. Kepelatihan Olahraga;Teori dan Metodologi.Bandung: PT.Remaja Randakarya.

Muhadjir. 2005. Teori dan Praktek Pendidikan Jasmani Untuk Kelas 1 SMP. Jakarta: PT. Ghalia Indonesia.

Oliver, John. 2007. Dasar-dasar Bola Basket ; Cara Yang Lebih Baik Untuk Mempelajarinya. Bandung: Pakar Raya.

Perbasi.1990. Pedoman Pelatih Bola basket Modern. Jakarta: Perbasi

Rahantoknam, B. Edward. 1988. Belajar Motorik; Teori dan Aplikasinya Dalam Pendidikan Jasmani dan Olahraga. Jakarta: P2LPTK Ditjen DiktiDepdikbud.

Soebagyo Hartoko. 1992. Teori dan Praktek Bola Basket I. Surakarta : FKIP UNS

Sudjana. 2002. Desain dan Analisis Eksperimen. Bandung: Tarsito.

Sugiyanto dan Sudjarwo, 1994. Perkembangan Gerak dan Belajar Gerak. Jakarta: Depdikbud.

Sucipto, Dian Budiana, Lukmanul Hakim Lubay \& Jajat Darajat.2010. Permainan Bola Basket. Bandung: Universitas Pendidikan Indonesia.

Winkel, W.S. 1996. Psikologi Pengajaran. Jakarta: PT Gramedia Widia sarana Indonesia.

Wissel, Hal. 2000. Bola Basket ; Langkah Untuk Sukses. Jakarta: PT.Raja Grafindo Persada.

\section{Biodata Penulis :}

$\begin{array}{ll}\text { Nama } & \text { : Wisnu Mahardika. Agus Supriyoko } \\ \text { Pendidikan } & \text { : S1 UNS Surakarta } \\ & \text { S2 Ilmu Keolahragaan UNS Surakarta } \\ \text { Pekerjaan } & : \text { Dosen POK-FKIP Universitas Tunas Pembangunan } \\ & \text { Surakarta } \\ \text { Alamat Kantor } & \text { : FKIP UTP Surakarta J1. M. Walanda Maramis No.31 } \\ & \text { Cengklik Surakarta Telp./Fax. : 0271854188 }\end{array}$

